\title{
Bernard Mandy (1948-2016)
}

\section{(2) OpenEdition}

\section{Journals}

Édition électronique

URL : http://journals.openedition.org/rao/2891

DOI : $10.4000 /$ rao. 2891

ISBN : 978-2-7535-5014-8

ISSN : $1775-3732$

\section{Éditeur}

Presses universitaires de Rennes

\section{Édition imprimée}

Date de publication : 31 décembre 2015

ISBN : 978-2-7535-5012-4

ISSN : 0767-709X

Référence électronique

"Bernard Mandy (1948-2016) », Revue archéologique de l'Ouest [En ligne], 32 | 2015, mis en ligne le 28 avril 2016, consulté le 02 mars 2021. URL : http://journals.openedition.org/rao/2891 ; DOI : https:// doi.org/10.4000/rao.2891 


\section{Bernard MANDY}

\section{(1948-2016)}

La Revue Archéologique de l'Ouest vient de perdre brutalement son directeur de publication, en poste depuis seulement un peu plus de deux ans. C'est au terme d'une carrière toute entière vouée au service public que Bernard Mandy avait été élu, en décembre 2013, Président de l'Association pour la diffusion des recherches archéologiques dans l'Ouest de la France qui constitue le comité scientifique et éditorial de la revue.

En charge successivement du service archéologique municipal de Lyon (1980-1989), du service régional de l'archéologie de Basse-Normandie (1989-1995) puis de celui des Pays-de-la-Loire (1995-2007), il avait ensuite exercé au niveau national la responsabilité des publications au sein de la sous-direction de l'archéologie.

La $R A O$ lui rendra hommage dans son prochain numéro.

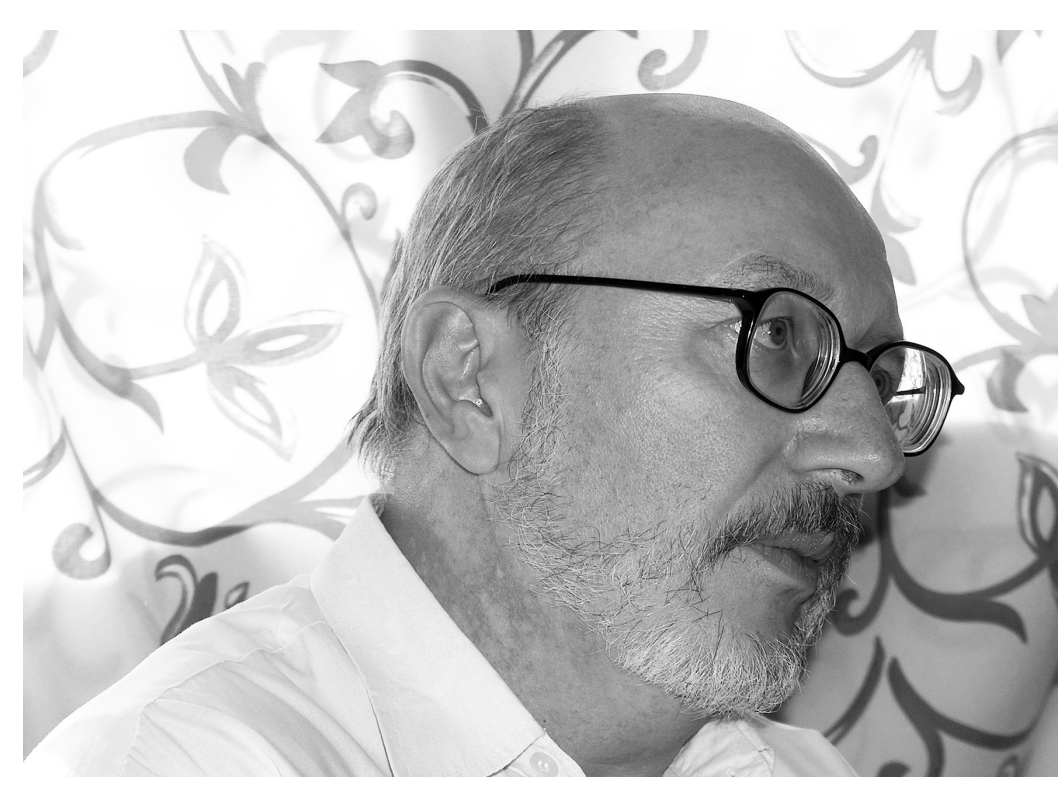

